\title{
ANALISIS RANCANGAN ANTARMUKA APLIKASI SISTEM MANAJEMEN PROPERTI PADA PT. XYZ
}

\author{
Alusyanti Primawati \\ Program Studi Teknik Informatika, Universitas Indraprasta PGRI \\ Email: alus.unindra23@gmail.com
}

\begin{abstract}
Abstrak
PT.XYZ merupakan perusahaan yang menyewakan propertinya untuk mendukung usaha perdagangan. Perusahaan PT. XYZ yang bergerak di bidang manejemen properti merupakan salah satu perusahaan yang sudah mengecap hasil dari penggunaan sistem yang terkomputerisasi. Akan tetap isi stem tersebut belum berkembang dengan menggunakan aplikasi yang terintegrasi sehingga memudahkan untuk membuat laporan akhir bulan ataupun tahunan. Oleh sebab itu maka ditemukan rumusan masalah yaitu bagaimana merancang aplikasi untuk mendukung sistem manajemen properti PT.XYZ. Metode yang digunakan adalah grounded research. Hasilnya adalah rancangan antarmuka yang didokumentasikan dalam Lembar Kerja Tampilan (LKT) serta Jaringan Semantik Tampilan (JST) dari aplikasi Sistem Manajemen Properti PT. XYZ melalui analisis perancangan dengan pendekatan orientasi objek menggunakan UML (Unified Modeling Language).
\end{abstract}

Kata Kunci: LKT, Jaringan Semantik Tampilan, Sistem Manajemen Properti.

\section{Pendahuluan}

Perkembangan teknologi semakin pesat khususnya di bidang informasi. Hal ini banyak ditemukan pada perusahaan dan instansi negara yang sudah banyak mengimplementasikan teknologi informasi dalam sistemnya. Dalam mengimplementasikan sebuah sistem ada 2 pilihan yaitu secara manual atau komputerisasi. Sistem yang terkomputerisasi tentunya memilikan keefektifan yang lebih baik dibandingkan sistem manual karena selain mempermudah segala pekerjaan untuk mencapai tujuan tertentu dalam penyimpanan, pengeditan data atau pencarian data tanpa harus membokar loker penyimpanan, sistem terkomputerisasi mampu menciptakan sebuah informasi yang terintegritas dan lepas dari masalah data yang ganda. Maka pada akhirnya setiap proses bisnis dan mengambil keputusan pun dapat dilakukan dengan lebih mudah tanpa kuatir kehilangan data atau data yang rangkap karena sudah memiliki acuan yang dalam sistem. PT.XYZ merupakan perusahaan yang menyewakan propertinya untuk mendukung usaha perdagangan. Perusahaan PT. XYZ yang bergerak di bidang manajemen properti merupakan salah satu perusahaan yang sudah mengecap hasil dari penggunaan sistem yang terkomputerisasi. Akan tetapi sistem tersebut belum berkembang dengan menggunakan aplikasi yang terintegrasi sehingga memudahkan untuk membuat laporan akhir bulan ataupun tahunan. Oleh sebab itu maka ditemukan rumusan masalah yaitu bagaimana merancang aplikasi untuk mendukung sistem manajemen properti PT.XYZ.

\section{Metodologi}

Metode yang digunakan untuk menyusun penulisan makalah ini adalah grounded research melalui survey, wawancara, dan observasi langsung. Analisis dan perancangan sistem dianalisis dengan Unified Modelling Language (UML) dan perancangan tampilan digambarkan dengan menggunakan tools Lembar Kerja Tampilan (LKT) dan Jaringan Semantik Tampilan (JST). Ruang lingkup penulisan ini adalah hanya sampai pada perancangan tampilan interface dari sistem manajemen properti di PT XYZ.

\section{Tinjauan Pustaka}

Dalam tahapan perancangan (design) bertujuan untuk merancang sistem baru yang dapat menyelesaikan masalah-masalah yang dihadapi perusahaan yang diperoleh dari pemilihan alternatif sistem yang terbaik. Kegiatan yang dilakukan dalam tahap perancangan ini 
meliputi perancangan output, input, dan file (Al-Bahra Bin Ladjamudin, 2005). Oleh sebab itu dibutuhkan analisis kebutuhan melalui skenario sistem yang sudah terbentuk sebelumnya. Dengan demikian diperoleh spesifikasi perangkat lunak yang diharapkan dengan keinginan dan kebutuhan pengguna, para pengembang melakukan pemodelan-pemodelan secara visual. Menurut Nugroho (2005), pemodelan visual adalah proses penggambaran informasiinformasi secara grafis dengan notasi-notasi baku yang telah disepakati sebelumnya demi suatu alasan yaitu komunikasi.

Salah satu cara pendekatan untuk merancang sebuah sistem adalah menggunakanUML (Unified Modeling Language) yang merupakan sebuah bahasa yang berdasarkan grafik/gambar untuk memvisualisasi, menspesifikasikan, membangun, dan pendokumentasian dari sebuah sistem pengembangan software berbasis OO (ObjectOriented).

Alat Bantu yang digunakan dalam Analisis dan Perancangan Berorientasi Objek sebagai berikut (Sholig,2006): Skenario, package, use case diagram, relasi, diagram aktivitas, diagram interaksi, State Diagram, Perancangan Basis Data, dan lainnya. Perancangan orientasi objek ini diharapkan lebih mudah dipahami dibandingkan perancangan terstruktur. Aplikasi yang dirancang mulai akan terlihat ketika tampilan antarmuka sudah dirancang berdasarkan analisis dari proses bisnis dan alat bantu perancangan.

Dalam merancang antarmuka, hal yang sangat perlu diperhatikan adalah bahwa disetiap pekerjaan perlu dilakukan dokumentasi, sehingga apabila ingin merubah rancangannya atau menyesuaikan rancangannya dengan keinginan user, perancang hanya memerlukan penyesuaian saja. Salah satu dokumentasi perancangan kerja dengan Lembar Kerja Tampilan dan untuk menentukan navigasinya maka dibuatlah sebuah bagan yang disebut jaringan semantic tampilan. (Sudarmawan dan Ariyus, 2007)

\section{Hasil dan Pembahasan \\ Proses Bisnis}

Hasil analisis proses bisnis PT. XYZ adalah:

1. Pengolahan Data Properti

Pada proses ini, semua properti milik PT. XYZ disimpan termasuk atribut yang dimiliki properti tersebut. Data properti akan berintegrasi dengan transaksi tenant dan vendor.

2. Pengolahan Transaksi Tenant (Penyewaan)

Tenant merupakan pihak penyewa properti yang dimiliki PT. XYZ. Tenant melakukan penyewaan berdasarkan persediaan properti yang ada, jika sudah ada kesepakatan maka dilakukan persetujuan kontrak diantara kedua pihak.

3. Pengolahan Transaksi Vendor

Vendor merupakan pihak perusahaan lain yang bekerjasama dengan PT. XYZ untuk mendukung proses pemeliharan properti, baik atas dasar permintaan tenant ataupun PT. $X Y Z$. Vendor yang menangani semua komplain yang diajukan oleh tenant kepada pihak PT. XYZ.

4. Laporan

Pada proses ini akan dilaporans emua yang terkait properti, semuatransaksi, dan pemeliharaan properti kepada Pimpinan PT. XYZ.

\section{Skenario Sistem Manajemen Properti PT. XYZ}

Berdasarkan proses bisnis maka diperoleh rancangan scenario sistem manajemen properti PT. XYZ adalah:

1. Staf menyimpan semua data tentang properti.

2. Jika ada properti baru maka, staf wajib melakukan pembaharuan data.

3. Calon tenant dating untuk melakukan proses penyewaan.

4. Staf memberikan info properti yang masih tersedia.

5. Tenant memilih properti dan meminta kontrak. 
6. Staff melakukan persetujuan dan menyiapkan berkas kontrak yang wajib diisi oleh tenant.

7. Tenant mengisi form data tenant, form kontrak, dan helpdesk.

8. Staff wajib melakukan pengecekan kelengkapan data.

9. Jika sudah lengkap dan persetujuan kontrak sudah divalidasi pimpinan, maka staf wajib memperbaharui data transaksi tenant.

10. Setiap terjadi transaksi yang dilakukan tenant termasuk pembayaran sewa pertama, maka staf akan mengeluarkan tagihan berdasarkan keluaran proses sistem transaksi tenant.

11. Tenant melakukan pembayaran sesuai tagihan (billing) yang diterimanya dari staf PT. XYZ.

12. PT. XYZ memiliki vendor yang berfungsi untuk mengatasi pemeliharaan properti.

13. Jika properti yang disewa tenant mengalami kerusakan atau permasalahan lainnya maka tenant diberikan hak untuk mengajukan complain kepada PT. XYZ.

14. Vendor selanjutnya akan ditugaskan oleh PT. XYZ untuk menyelesaikan komplain.

15. Setiap pemeliharaan properti yang dilakukan vendor wajib melalui melengkapi data yang dibutuhkan staf sehingga dapat diproses transaksi yang dilakukan vendor.

16. Pemeliharaan properti tidak hanya atas permintaan tenant tetapi juga bisa dilakukan oleh vendor itu sendiri.

17. Staf dapat mencetak laporan bulanan dari aplikasi untuk diserahkan kepimpinan.

\section{Model Bisnis Sistem}

\section{Sequence Diagram}

Penggambaran event dari sistem manajemen properti yaitu:

a. Pengolahan Data Properti

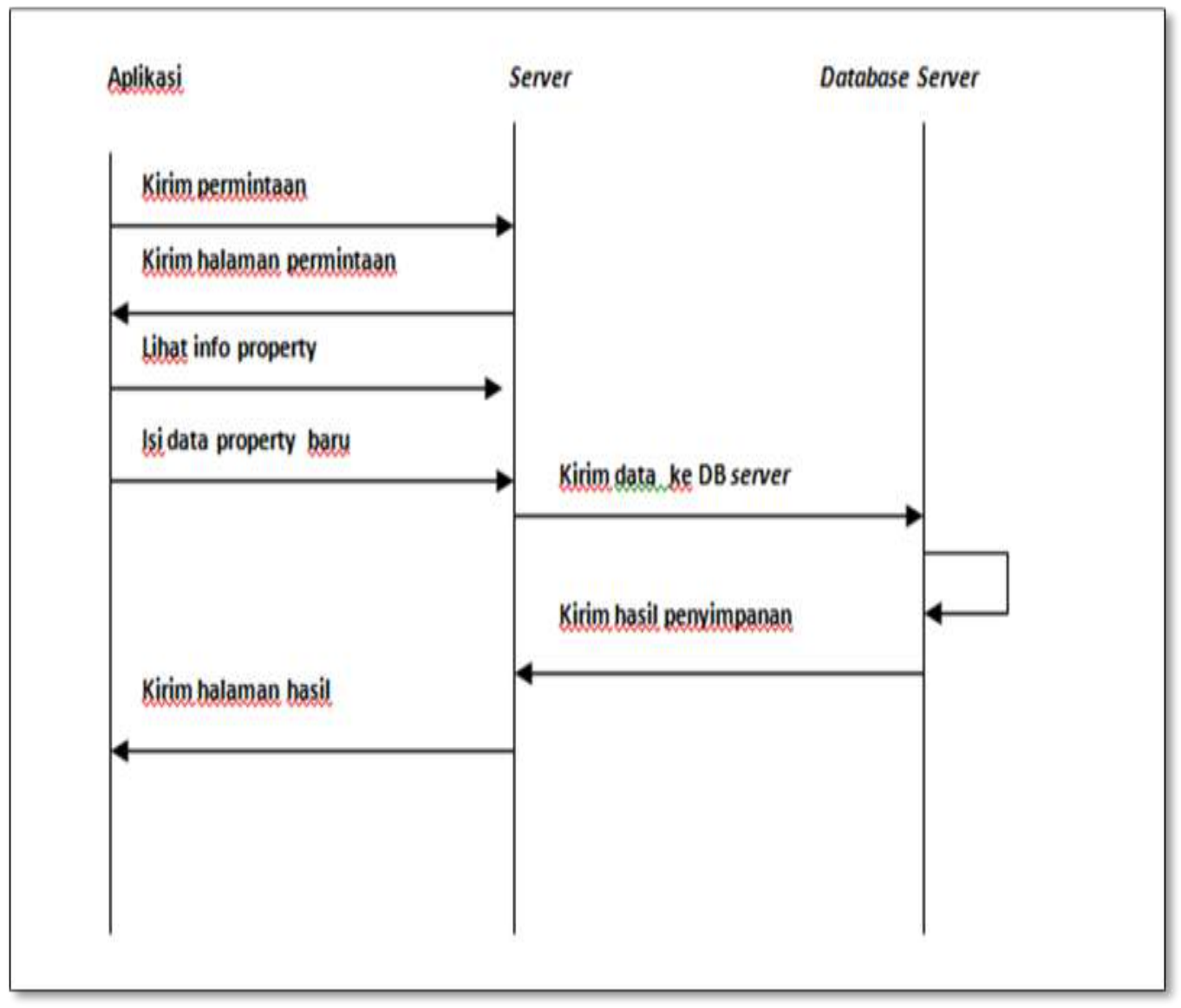

Gambar 1. Sequence Diagram Pengolahan Data Properti 
b. Pengolahan Transaksi Tenant

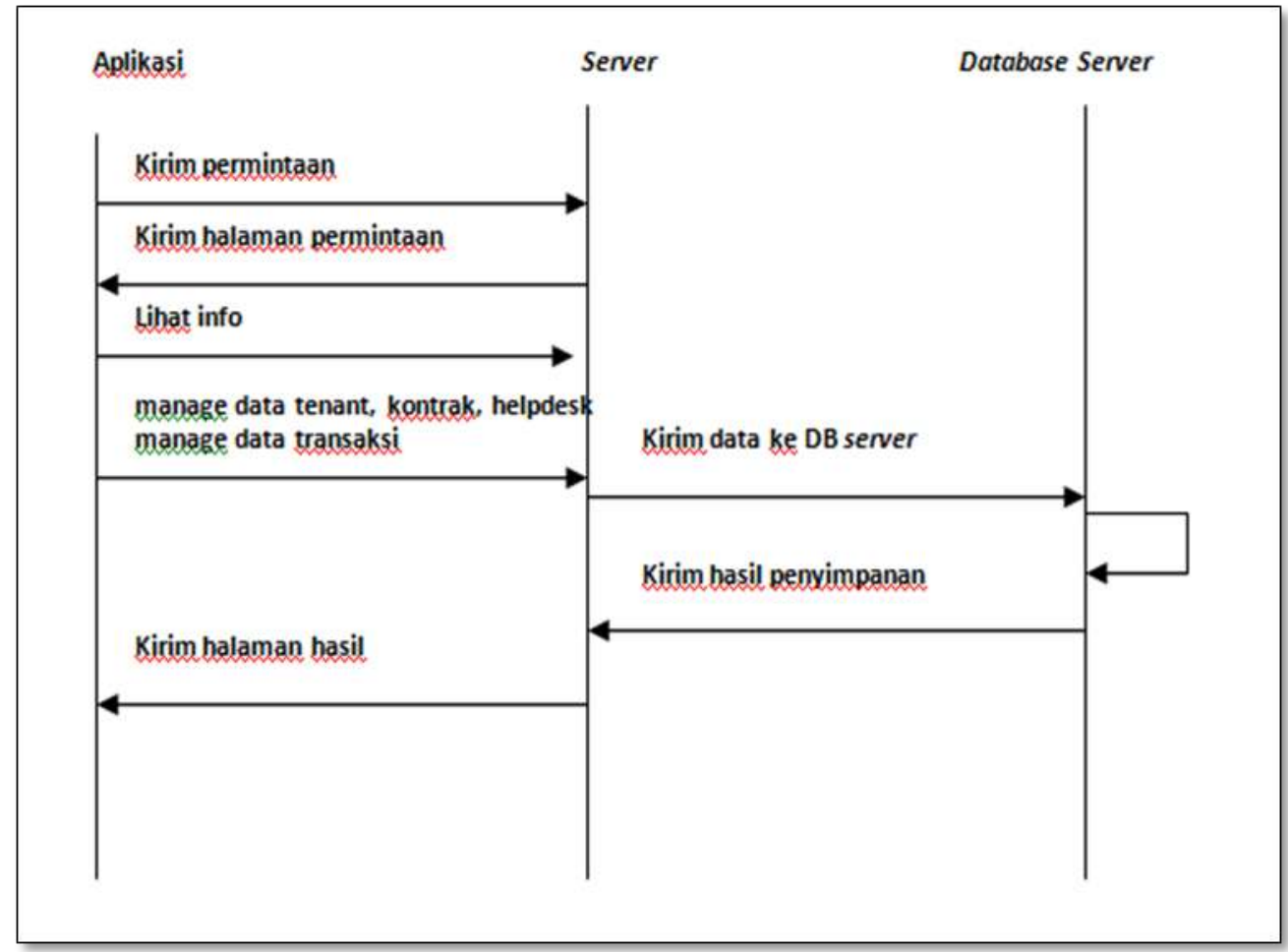

Gambar 2. Sequence Diagram Pengolahan Transaksi Tenant

c. Pengolahan Transaksi Vendor

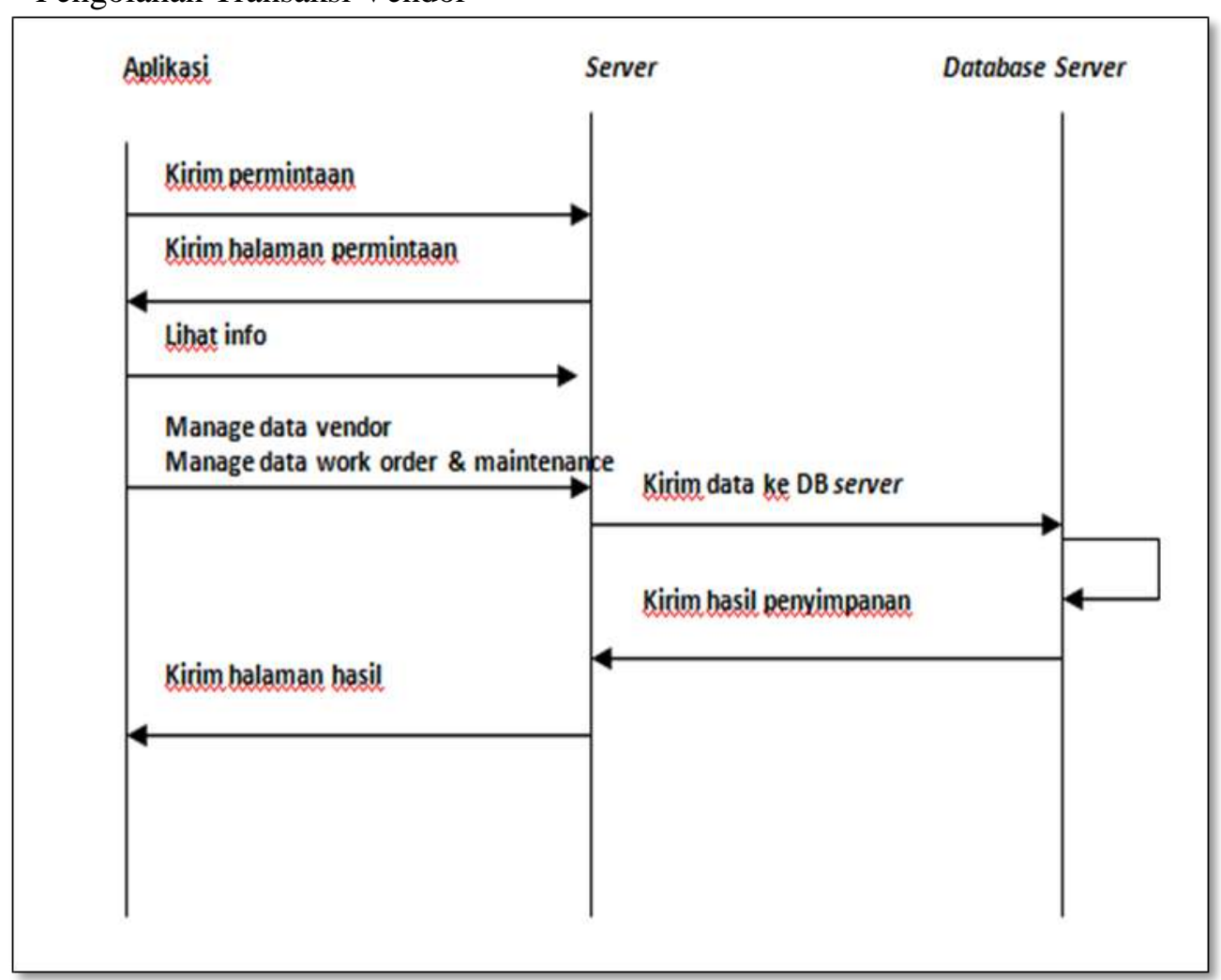

Gambar 3. Sequence Diagram Pengolahan Transaksi Vendor 
d. Laporan

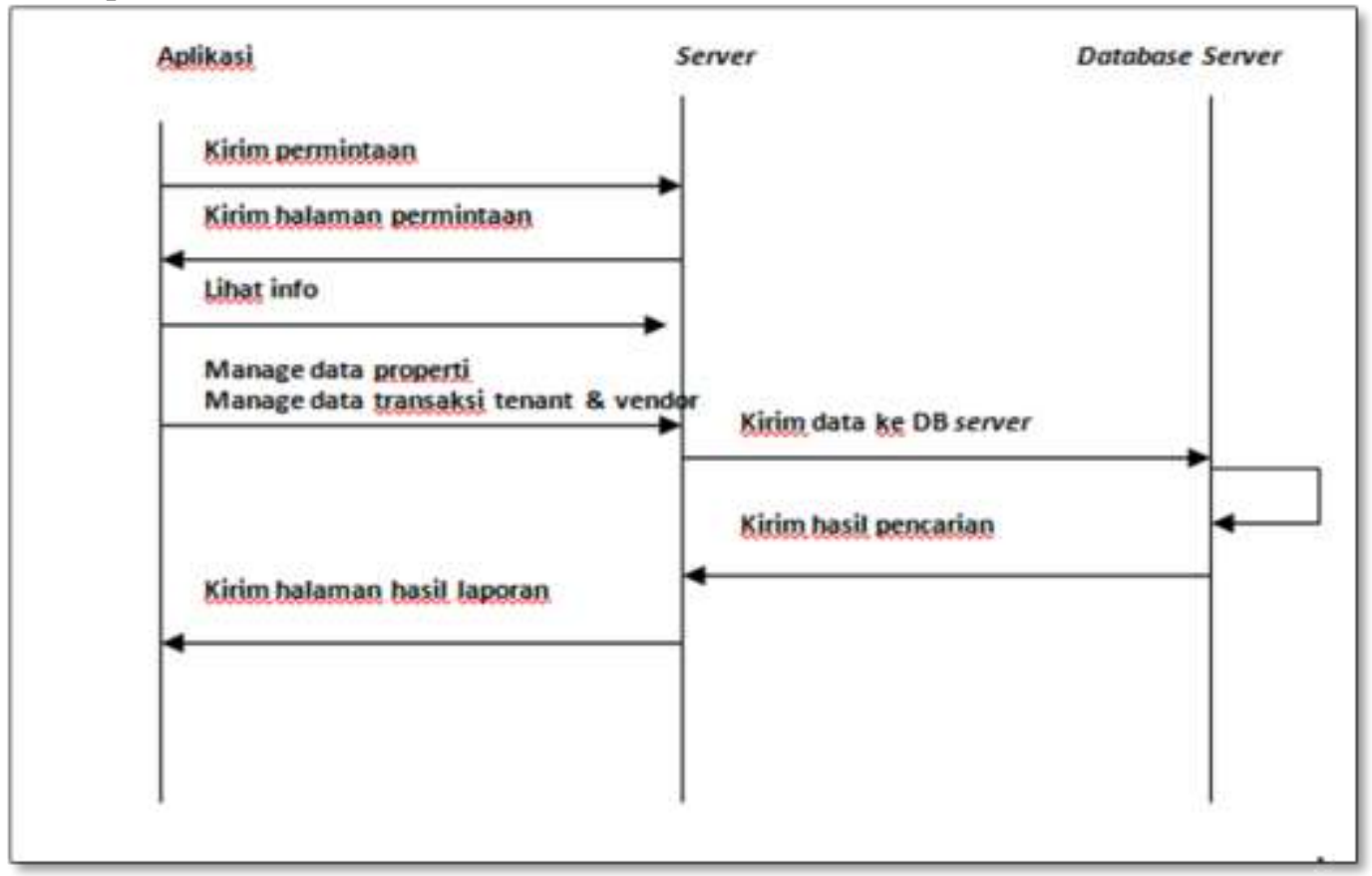

Gambar 4. Sequence Diagram Pengolahan Laporan

\section{State Diagram}

a. Pengolahan Transaksi Tenant

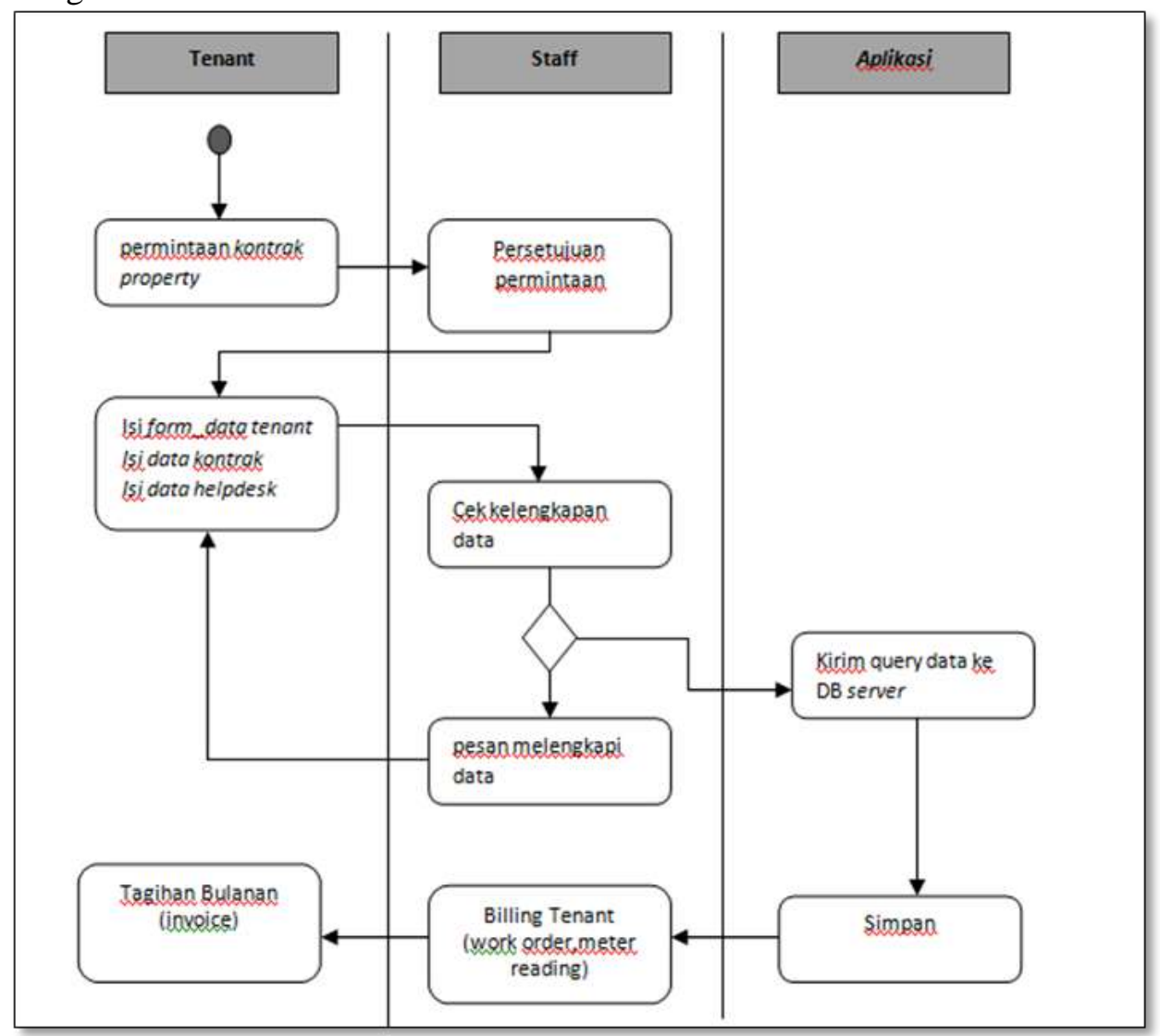

Gambar 5. State Diagram Pengolahan Transaksi Tenant 
b. Pengolahan Transaksi Vendor

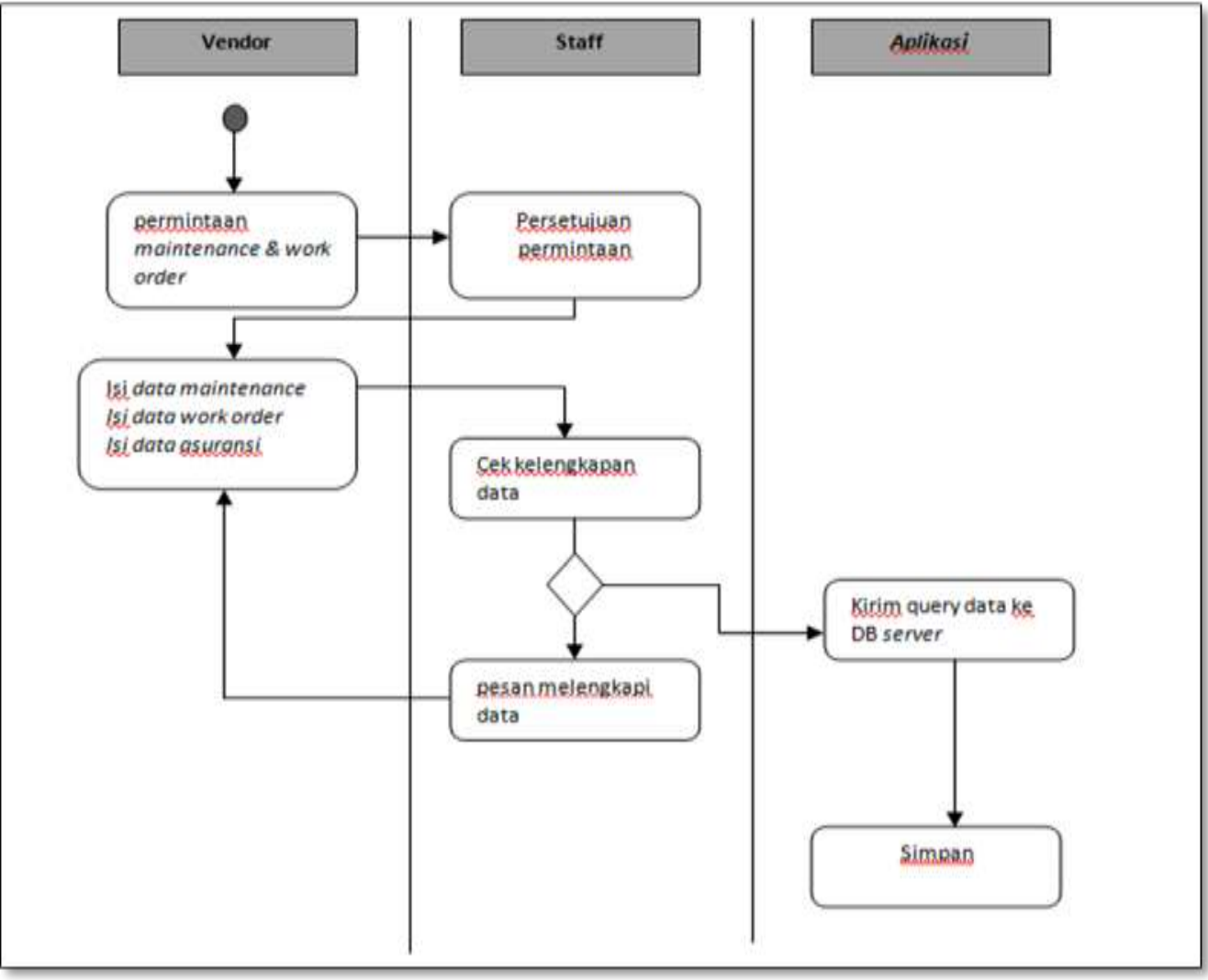

Gambar 6. State Diagram Pengolahan Transaksi Vendor

c. Laporan

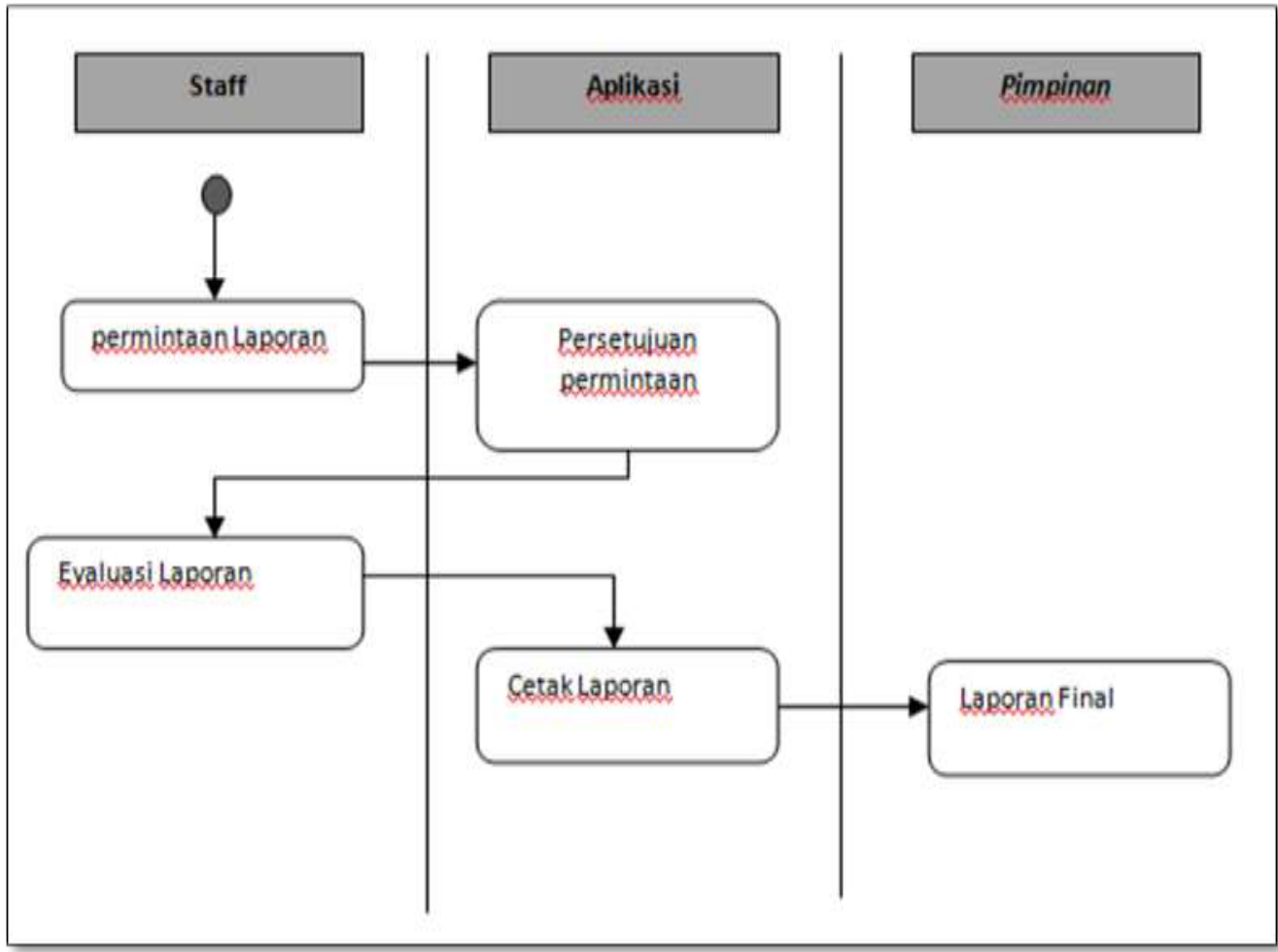

Gambar 7. State Diagram Laporan 


\section{Rancangan Layar}

1. Lembar Kerja Tampilan Masuk Aplikasi

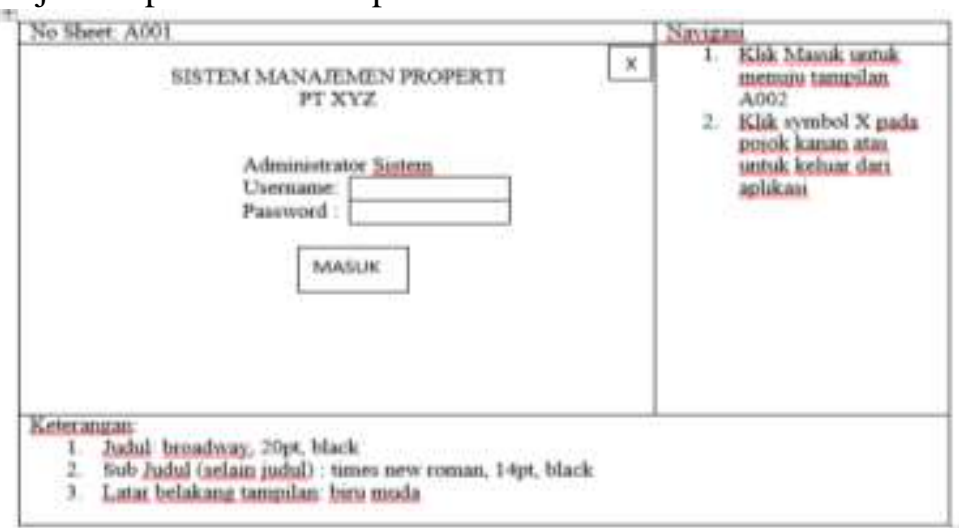

Gambar 8. Lembar Kerja Tampilan Masuk Aplikasi

2. Lembar Kerja Tampilan Beranda

\begin{tabular}{|c|c|c|}
\hline \multicolumn{2}{|l|}{ No. Sheet: $\mathrm{AOOZ}$} & \multirow{2}{*}{$\begin{array}{l}\text { Daygas/ } \\
1 . \text { Klik Peneolahan }\end{array}$} \\
\hline PENGOLAHAN DATA & KELUAR & \\
\hline PROPERTI & \multirow[b]{6}{*}{$\begin{array}{l}\text { TEMEN PROPERTI } \\
\text { XYZ }\end{array}$} & \multirow{6}{*}{ 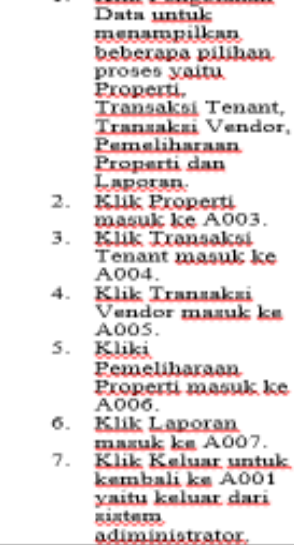 } \\
\hline TRANSAKSI TENANT & & \\
\hline TRANSAKSI VENDOR & & \\
\hline PEMELIHARAAN PROPERTI & & \\
\hline LAPORAN & & \\
\hline $\begin{array}{l}\text { SISTEMMANAJEMEN PROPERTI } \\
\text { PT XYZ }\end{array}$ & & \\
\hline 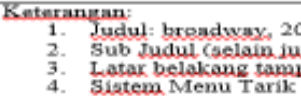 & $\begin{array}{l}k \\
\text { nes new roman, } 14 \mathrm{pt}, \\
\text { cu mauda }\end{array}$ & \\
\hline
\end{tabular}

\section{Gambar 9. Lembar Kerja Tampilan Beranda}

3. Lembar Kerja Tampilan Pengolahan Data Properti

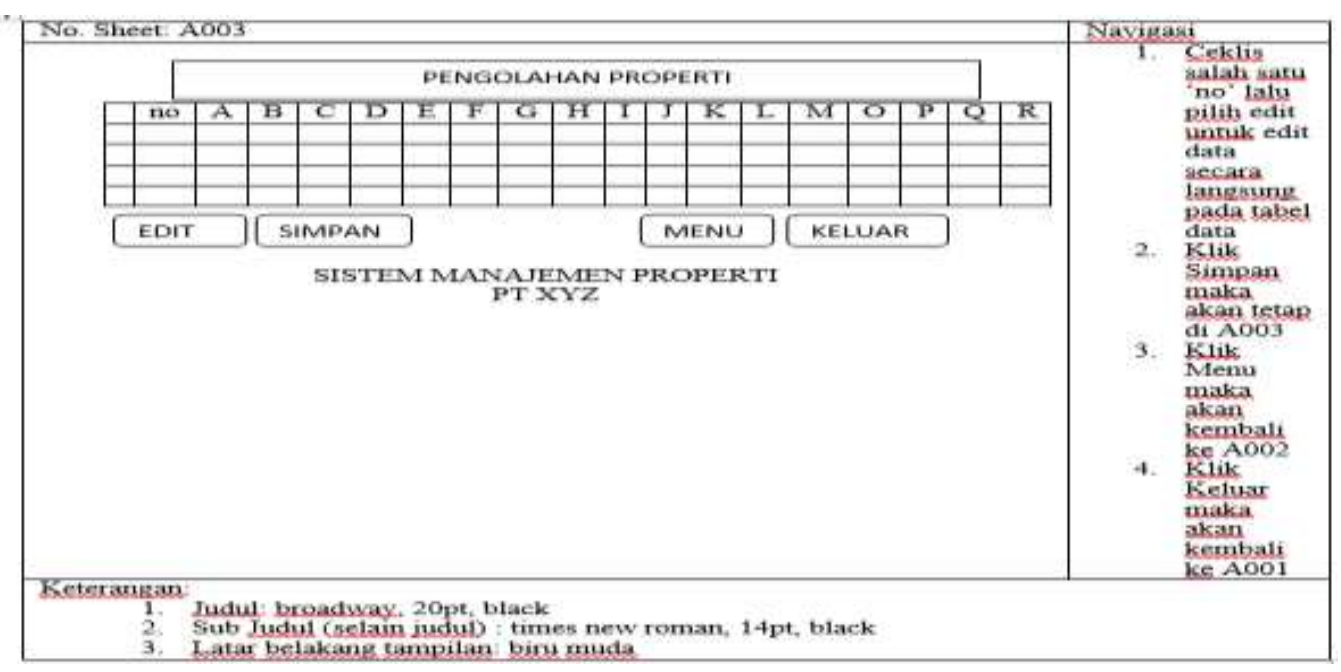

Gambar 10. Lembar Kerja Tampilan Pengolahan Data Properti 
4. Lembar Kerja Tampilan Pengolahan Transaksi Tenant

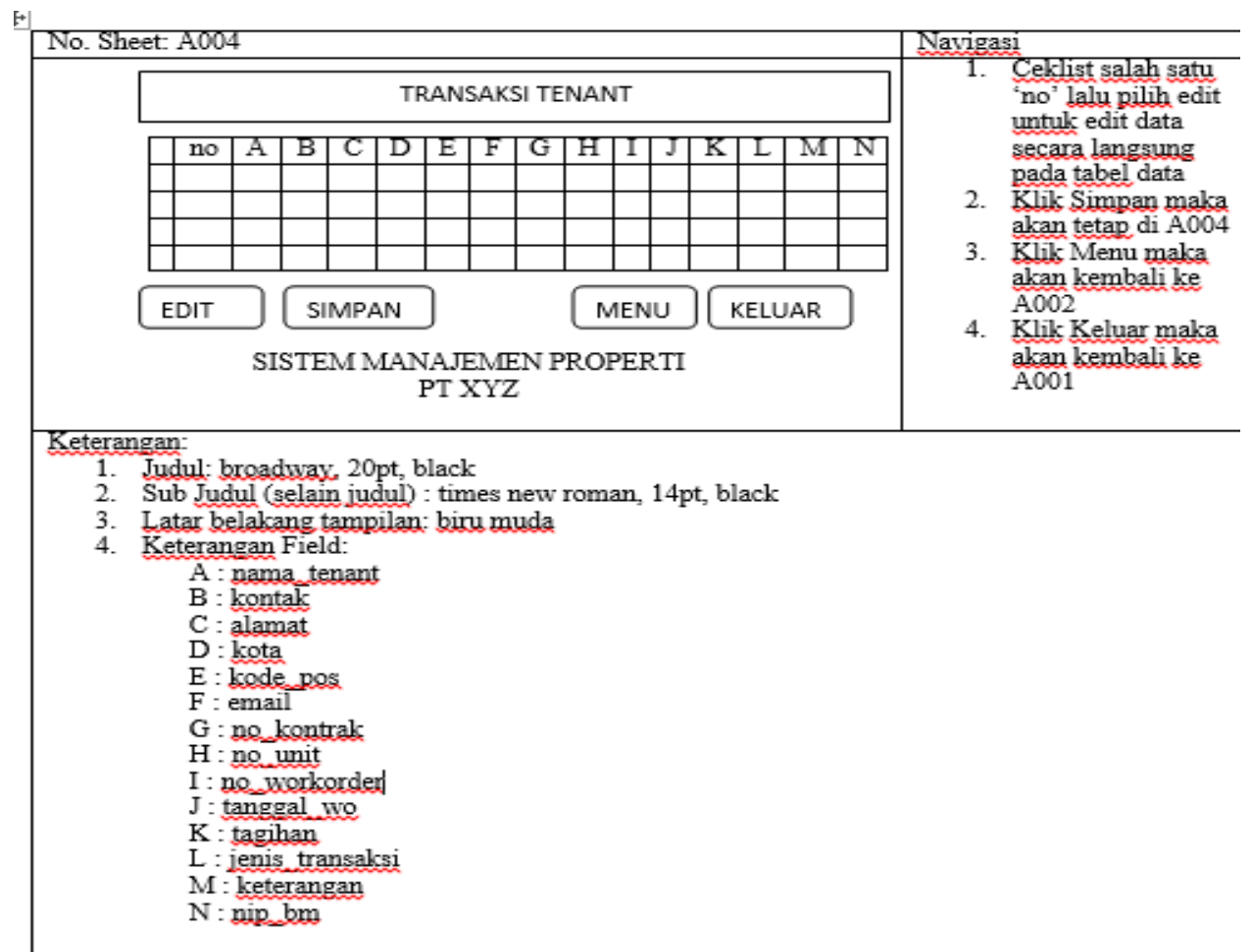

\section{Gambar 11. Lembar Kerja Tampilan Pengolahan Transaksi Tenant}

5. Lembar Kerja Tampilan Pengolahan Transaksi Vendor

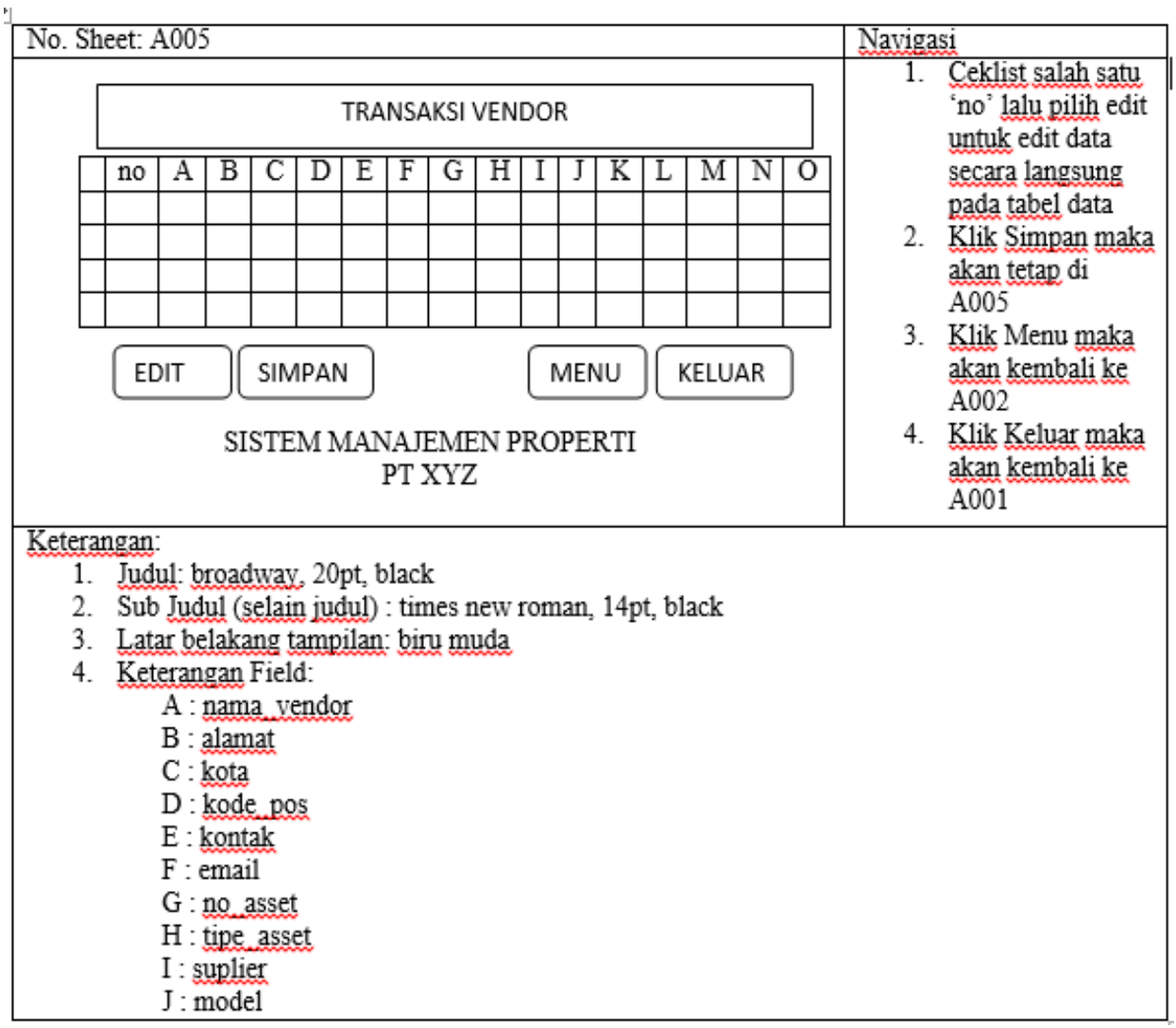

Gambar 12. Lembar Kerja Tampilan Pengolahan Transaksi Vendor 
6. Lembar Kerja Tampilan Pemeliharaan Properti

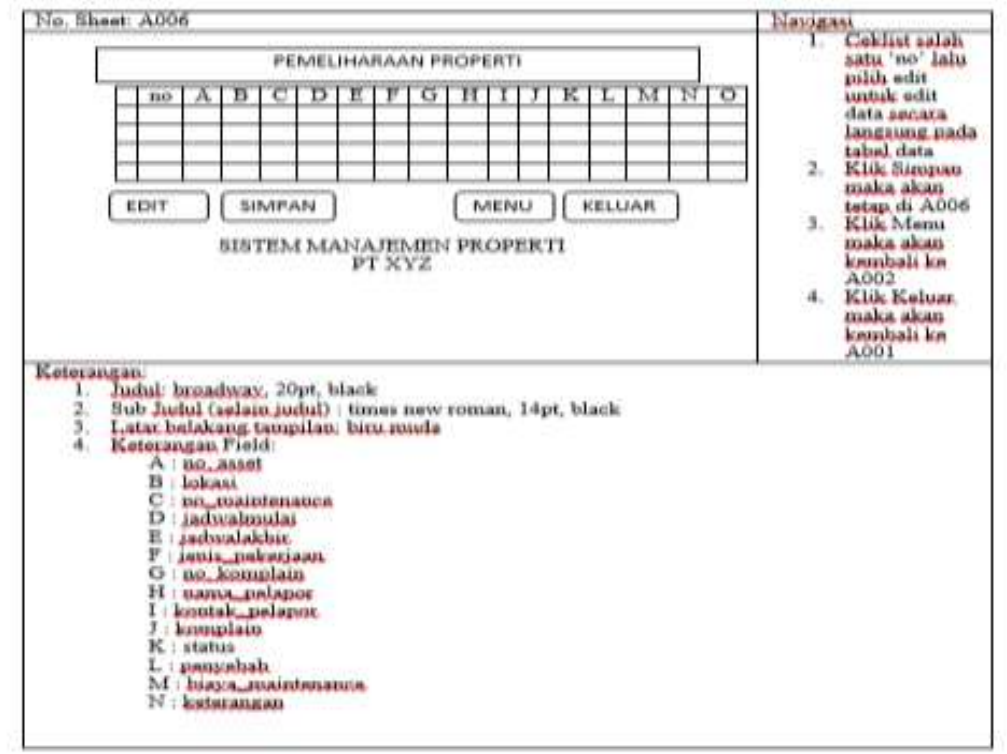

Gambar 13. Lembar Kerja Tampilan Pemeliharaan Properti

7. Lembar Kerja Tampilan Laporan

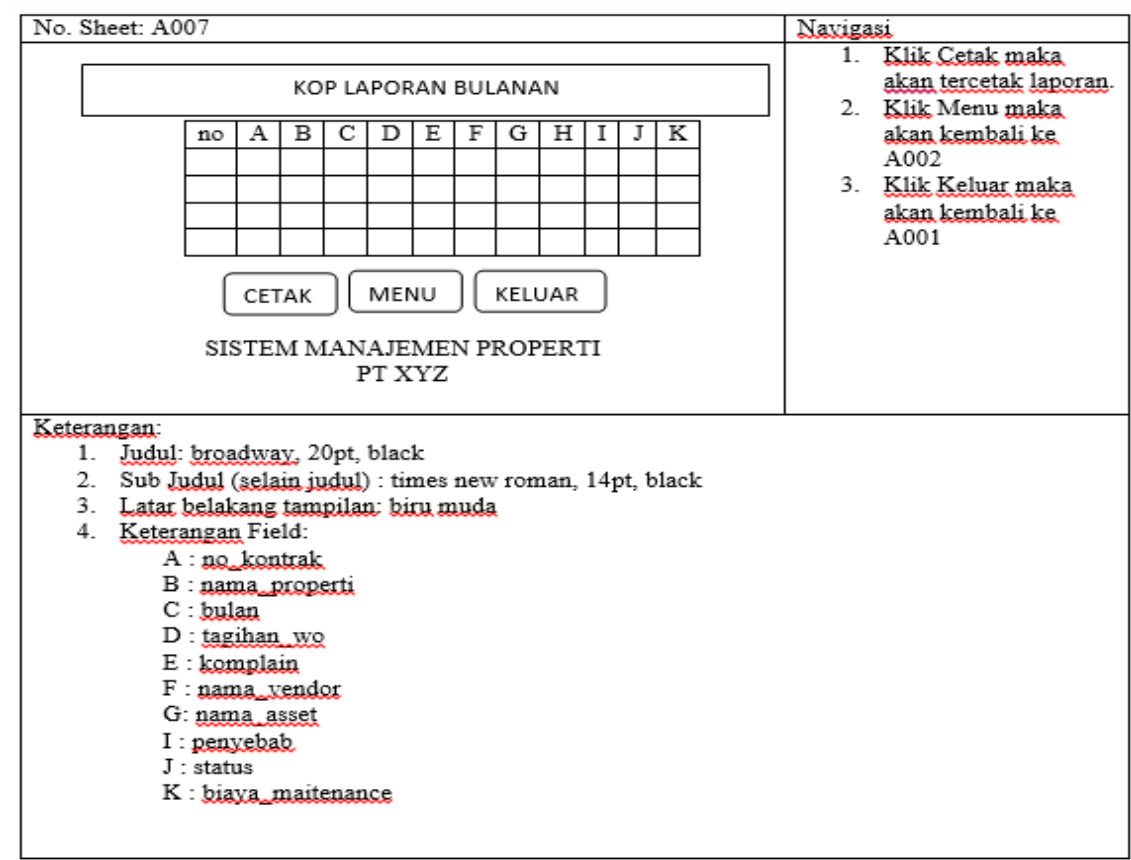

Gambar 14. Lembar Kerja Tampilan Laporan

Jaringan SemantikTampilan

Hubungan antar tampilan dapat digambarkan melalui jaringan semantik tampilan seperti pada gambar 15 . 


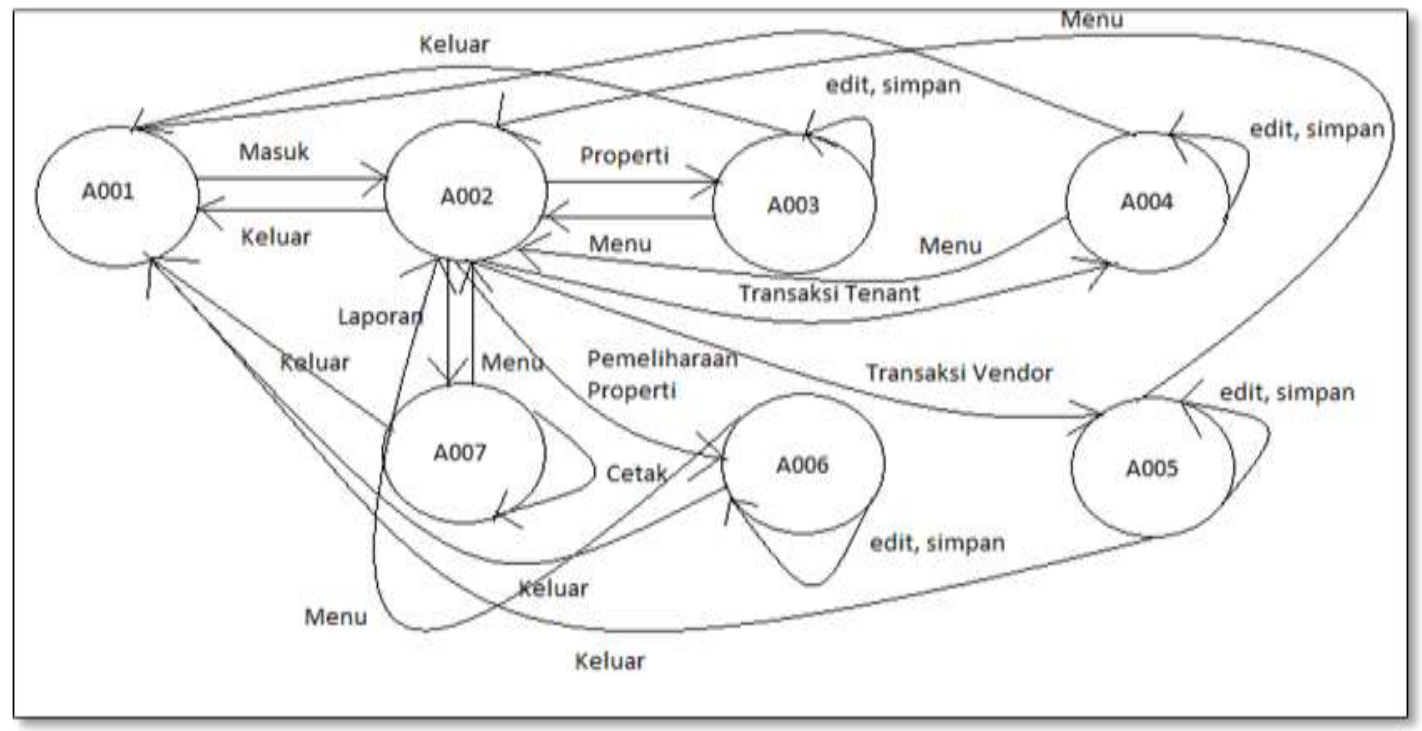

\section{Gambar 15. Jaringan Semantik Tampilan Rancangan Aplikasi Sistem Manajemen Properti PT. XYZ}

\section{Simpulan}

Dengan adanya sistem manajemen properti yang didukung oleh aplikasi atau perangkat lunak khusus maka diharapkan akan mempermudah seluruh proses bisnis didalam PT. XYZ hingga tahap pelaporan. Hasil rancangan antarmuka aplikasi melalui dokumentasi Lembar Kerja Tampilan (LKT) ini diharapkan dapat menjadi referensi pada karya tulis selanjutnya yang dikembangkan kedalam implementasi aplikasi dengan menggunakan bahasa pemograman desktop ataupun web.

\section{Daftar Pustaka}

Al-Bahra Bin Ladjamudin. (2005). Analisis dan Desain Sistem Informasi. Yogyakarta: Graha Ilmu.

Nugroho, A. (2002). Analisis dan Perancangan Sistem Informasi dengan Menggunakan Metodologi Berorientasi Objek. CetakanPertama: Bandung: Informatika.

Sholiq. (2006). Pemodelan Sistem Informasi Berorientasi Objek dengan UML. Yogyakarta: Graha Ilmu.

Sudarmawan dan Ariyus, D. (2007). Interaksi Manusia \& Komputer. Yogyakarta: Andi. 